How to cite this article:

Sarudin, A., Mohamaed Redzwan, H. F., Osman, Z., Raja Ma'amor Shah, R. N. F., \& Mohd Ariff Albkri, I. S. (2019). Menangani kekaburan kemahiran prosedur dan terminologi awal matematik: Pendekatan leksis berdasarkan teori prosodi semantik. Malaysian Journal of Learing and Insruction, 16 (2), 255-294.

\title{
MENANGANI KEKABURAN KEMAHIRAN PROSEDUR DAN TERMINOLOGI AWAL MATEMATIK: PENDEKATAN LEKSIS BERDASARKAN TEORI PROSODI SEMANTIK
}

\section{(ADDRESSING THE AMBIGUITY OF MATHEMATICAL PROCEDURAL SKILLS AND TERMINOLOGIES: A NOVEL LEXICAL APPROACH BASED ON THE PROSODIC SEMANTIC THEORY)}

${ }^{1}$ Anida Sarudin, ${ }^{2}$ Husna Faredza Mohamed Redzwan, ${ }^{3}$ Zulkifli Osman,

${ }^{4}$ Raja Noor Farah Azura Raja Ma'amor Shah \& ${ }^{5}$ Intan Safinas Mohd Ariff Albakri

${ }^{1,2,3 \& 5}$ Fakulti Bahasa dan Komunikasi, Universiti Pendidikan Sultan Idris, Perak, Malaysia

${ }^{4}$ Fakulti Sains dan Matematik, Universiti Pendidikan Sultan Idris,

Perak, Malaysia

${ }^{1}$ Corresponding author: anida@fbk.upsi.edu.my

Received: 22/1/2019 Revised: 9/7/2019 Accepted: 25/10/2019 Published: 24/12/2019

\section{ABSTRAK}

Tujuan - Kajian ini bertujuan mengenal pasti pedagogi guru awal Matematik dalam kalangan kanak-kanak di Pusat Anak PERMATA Negara (PAPN) dan mengenal pasti sejauh manakah pendekatan leksis berdasarkan Teori Prosodi Semantik dapat menjelaskan kekaburan kemahiran prosedur dan terminologi awal Matematik. 
Metodologi - Kajian ini melibatkan 20 orang guru dan 60 orang kanak-kanak yang berumur 4 tahun. Sebanyak 4 lokasi kajian dipilih, iaitu di PAPN Bercham, PAPN Sg. Siput, PAPN Teluk Intan dan PAPN Besout 1. Instrumen yang digunakan dalam kajian ini ialah soal selidik dan senarai semak pencerapan dan pemudahcaraan $(\mathrm{PdPc})$. Proses pencerapan PdPc hanya melibatkan 8 orang guru yang terpilih secara rawak. Kajian ini juga mengaplikasikan korpus daripada Pangkalan data Dewan Bahasa dan Pustaka (DBP) untuk meneliti kolokasi kata dan konteks berkaitan leksikal padanan, kumpul, mengasingkan dan banding.

Dapatan - Hasil kajian mendapati bahawa PdPc, guru mengajar konsep padanan dengan menjelmakan perkataan cari yang sama, pilih yang sama, sama tak bentuk, sama dengan, dan tarik, manakala konsep kumpul dijelmakan dengan leksikal seperti mengikut yang sama, dan ambil semua. Seterusnya konsep asing dijelmakan dengan leksikal kira, cuba kira, ambil, masukkan, cari dan mana. Seterusnya, konsep membanding diajarkan dengan menyebut leksikal bezakan dan yang mana. Pendekatan leksis berasaskan Teori Prosodi Semantik dapat menunjukkan konteks awal Matematik, iaitu konsep padanan, kumpul, asing dan membanding dengan tepat dari pelbagai perspektif kolokasi.

Signifikan - Kajian ini mengetengahkan pendekatan leksis yang dapat menawarkan strategi baharu dalam pengajaran awal Matematik berteraskan Teori Prosodi Semantik.

Kata Kunci: Kanak-kanak, pendekatan leksis, terminologi Matematik, kemahiran prosedur, Pusat Anak PERMATA Negara (PAPN), Teori Prosodi Semantik.

\begin{abstract}
Purpose - The purpose of this study is to identify teachers' pedagogy in the early Mathematics among students in Pusat Anak PERMATA Negara (PAPN). This study also seeks to examine how lexical analysis based on the Prosodic Semantic Theory could potentially clarify the ambiguity of the early Mathematical procedural skills and terminologies.
\end{abstract}


Methodology - Participants involved in this study include 20 teachers and 60 four- year-old students from four different locations; PAPN Bercham, PAPN Sg. Siput, PAPN Teluk Intan and PAPN Besout 1. Data was collected using two instruments; a questionnaire and Teaching and Learning observation checklist. Lesson observations were conducted on 8 randomly selected teachers. This study also applied the corpus from Dewan Bahasa dan Pustaka Databases (DBP) to examine the collocation of the concepts of matching, collecting, separating and comparing.

Findings - The findings suggest that the teachers taught matching concept by using words of similar meaning such as cari yang sama, pilih yang sama, sama tak bentuk, sama dengan, and tarik while in teaching the concept of collecting the teachers used synonymous lexical words such as mengikut yang sama, and ambil semua. The separating concept was also taught using synonymous lexical kira, cuba kira, ambil, masukkan, cari and mana. Subsequently, the comparing concept is taught by mentioning bezakan and yang mana. Evidently, the lexical approach based on the prosodic semantic theory was able to effectively present the concepts of early Mathematics, which are matching, collecting, separating and comparing from various collocation perspectives.

Significance - This study presents a lexical approach that offers a new strategy in the teaching of Mathematics based on the Prosodic Semantic theory.

Keywords: Children, lexical approach, Mathematics terminology, procedural skills, Pusat Anak PERMATA Negara (PAPN), Prosodic Semantic Theory.

\section{PENGENALAN}

Pembelajaran Matematik merupakan ilmu yang dapat mengembangkan potensi kognitif pelajar-pelajar ke arah pemikiran masa hadapan. Oleh itu, ilmu ini perlu diasah dan dipertajam sejak di peringkat awal bagi melahirkan pelajar yang kompeten dan mahir dalam bidang ini. Menurut Aunio dan Niemvirta, (2010), kemahiran awal Matematikialah peramal yang kuattentang kebolehan Matematik masa depan. Hal ini menggambarkan bahawa pendidikan awal 
Matematik perlu didedahkan dengan baik bagi memberikan peluang pembelajaran yang optimum. Guru, bertindak sebagai fasilitator, boleh memasukkan perbincangan kelas untuk menyediakan peluang terhadap kanak-kanak menjelaskan, mempertahankan, membuat kesimpulan, meramalkan, dan menyesuaikan cara mereka mengetahui konsep Matematik. Guru juga boleh menggalakkan pelajar untuk mewakili pemahaman mereka dalam pelbagai cara yang berbeza untuk menyokong perkembangan kemahiran berfikir kritis mereka.

Pendidik juga perlu membangun hubungan positif dengan cara menimbulkan pembelajaran serta memberikan ruang dan peluang kepada kanak-kanak, khususnya mengungkapkan pandangan peribadi mereka dalam konsep Matematik. Hubungan bahasa dan Matematik telah banyak dibincangkan dalam kajian-kajian terdahulu seperti kajian Aiken (1972), Bley-Vroman (1989), Bradby, Owing dan Quinn (1992) yang berpendapat bahawa terdapat hubungan yang positif penguasaan Matematik dalam bahasa. Antara bentuk kajian-kajian lalu telah memperbaiki kemahiran murid dalam mengungkapkan konsep dan idea Matematik menggunakan pelbagai perwakilan, meningkatkan kemahiran murid dalam penalaran Matematik, berdebat dan justifikasi serta membangunkan amalan pengajaran yang memupuk kemahiran Matematik dalam kalangan murid. Dengan kata lain, pembelajaran awal Matematik perlu dilakukan secara konteks yang bermakna. Menurut Bryant dan Nunes (2002) bagi menerbitkan pemikiran logik dalam kalangan kanak-kanak, pengajaran awal Matematik perlu dilakukan secara sistem pengiraan konvensional, dan konteks yang bermakna. Hal ini boleh dilakukan apabila guru dapat memberi kefahaman dengan baik akan makna bagi setiap konsep awal Matematik seperti pembelajaran prinsip-prinsip Matematik berkaitan maksud nombor, kemampuan untuk membandingkan, mengklasifikasikan dan memahami korespondensi dan keraguan satu sama lain.

Isu kesukaran kanak-kanak dalam memahami konsep dan prosedur awal Matematik yang bersifat abstrak dan simbolik menjadi titik tolak dalam usaha membentuk transformasi pengajaran dan pembelajaran awal Matematik kanak-kanak. Kekangan isu ini diprojeksikan melalui kegagalan guru-guru dalam menyampaikan pengajaran konsep mengikut terminologi dan prosedur awal Matematik melalui bahasa secara efisyen yang melunturkan minat dan penguasaan 
kanak-kanak dalam bidang ini. Kelemahan ini berpunca daripada kegagalan guru memahami matlamat Matematik, pembangunan Matematik kanak-kanak, aktiviti Matematik yang tidak kompeten, ujian Matematik yang tidak membantu pembangunan berfikir natural kanak-kanak serta bentuk konsep yang jelas dalam pengajaran. Selain itu juga, kajian oleh Clements dan Sarama (2014) menyatakan bahawa, Matematik merupakan asas pembangunan kognitif, namun guru tidak mengajar secara natural tentang terminologi dan kemahiran Matematik pada tahap umur mereka kerana kanak-kanak sering menggunakan pengalaman daripada dunia sekitarnya.

Oleh itu, kajian ini ingin meneliti sejauh mana medium bahasa berperanan dalam menterjemahkan operasi dan terminologi Matematik yang diterapkan secara kontekstual ataupun multikontekstual. Usaha mempergiat minat dan kefahaman yang dominan terhadap mata pelajaran awal Matematik dalam kalangan para guru dan awal kanak-kanak diperlihat dalam banyak amalan praktikal yang meliputi strategi-strategi pengajaran yang bersifat instrumen dan prosedural. Namun begitu, prestasi, kefahaman serta minat awal kanak-kanak dan murid sekolah rendah masih lagi berada pada tahap memuaskan berdasarkan kajian-kajian yang telah dilakukan seperti kajian Starkey, P dan Klein (2008), Rudd et. al (2008), Tengku Zainal, Mustapha dan Abdul Razak (2009), Mohd Kosnin dan Mohd Khalid (2010), Loretta et.al. (2010), Clements et.al. (2014) dan Chong et.al. (2017). Kekangan atau masalah yang berlaku antaranya berkisar kepada permasalahan pedagogi guru yang masih lagi bercorak tradisional, iaitu hafalan dan gagal menerapkan kefahaman yang jitu dalam penguasaan dan konsep mengikut prosedur dan terminologi Matematik. Kelemahan dan kepincangan yang berlaku ini berpunca daripada kepercayaan dan tahap penguasaan pedagogi isi kandungan yang kurang menyerlah dalam kalangan guru-guru prasekolah yang secara tidak langsung mencetuskan impak dalam pengetahuan Matematik kanak-kanak prasekolah. Dalam banyak kajian mengesahkan bahawa guru prasekolah masih lemah dalam mengajarkan sesuatu konsep pelajaran awal Matematik dan adakalanya andaian mereka salah. Dalam konteks ini, bermaksud pembentukan konsep yang berlaku dalam fikiran para guru prasekolah adalah berbeza dengan hasrat yang ingin dicapai oleh kurikulum awal Matematik itu sendiri.

Kegagalan kanak-kanak dalam penguasaan konsep dan kemahiran Matematik akan mengekang pemupukan minat terhadap 
pembelajaran tersebut yang secara tidak langsung menjadi halangan dalam mencapai aspirasi pendidikan secara keseluruhan dan aspirasi murid secara individu seperti yang dilakarkan dalam Pelan Pembangunan Pendidikan Negara (2013-2025). Hal ini demikian kerana, pedagogi guru dan cara belajar kanak-kanak prasekolah gagal menghubungkaitkan aspek akses, kualiti, ekuiti, perpaduan dan kecekapan murid yang terangkum dalam kurikulum itu sendiri dengan keberhasilan murid yang bercirikan pengayaan pengetahuan, ketinggian berfikir dan memiliki etika dan kerohanian yang unggul. Konflik yang berlaku ini disebabkan oleh pengetahuan awal Matematik dipengaruhi oleh pengajaran berbentuk hafalan konsep dan prosedur yang lebih cenderung kepada amalan yang konkrit. Misalnya, dalam kurikulum prasekolah, pembelajaran awal Matematik lebih mengacu kepada pembelajaran hands-on atau pembelajaran maujud yang bermakna. Namun begitu, guruguru prasekolah tidak menyedari bahawa bukan semua pemahaman konsep dan proses awal Matematik diterjemahkan bersandarkan bahan-bahan instrumental ini, malah perlu juga diiringi dengan penerangan secara berperkataan berkaitan bidang ini. Hal ini diperkukuh dengan pandangan Jamison (2000) bahawa aspek bahasa penting dalam pengajaran Matematik kerana struktur bahasa yang tepat dapat meningkatkan kefahaman mereka tentang konsep asas Matematik.

Penggunaan bahasa dalam pembelajaran dan pemudahcaraan awal $(\mathrm{PdPc})$ Matematik perlu disertai dengan teori atau model bahasa yang efisien bagi menangani kekaburan dalam memahami konsep mengikut terminologi dan prosedur Matematik awal secara relasional. Kekangan dari sudut bahasa berperkataan yang digunakan oleh para guru prasekolah dalam pengajaran dan pembelajaran awal Matematik diterjemahkan melalui kegagalan guru menggunakan istilah yang tidak tepat dalam menggambarkan terminologi dan prosedur dalam bidang ini. Konflik ini telah menyebabkan pemahaman terhadap sesuatu konsep awal Matematik dan kemahiran prosedur yang diajar menjadi lebih kompleks kerana kanak-kanak sukar menggarap makna daripada istilah dan konstruk dalam operasi awal Matematik. Kajian masalah dan kesukaran terhadap Matematik berperkataan telah banyak dikaji seperti Clement (1980) dan Stern (1993) yang mendapati bahawa murid menghadapi masalah dalam menggarap istilah dan arahan soalan yang melibatkan penyelesaian masalah melalui pemahaman prosedur Matematik. Hal ini membuktikan 
terdapat kepincangan dan konflik yang harus dibendung mulai dari peringkat awal berkaitan kekaburan menggarap istilah Matematik mengikut kemahiran prosedur dan terminologi dalam menguasai bidang ini. Kajian susulan menangani hal ini telah banyak dilakukan dengan menjadikan wahana bahasa sebagai medium penyelesaiannya misalnya, kajian Mrozek (2000) dan Mohamad Ashari et al. (2013) mendapati bahawa strategi berperkataan yang sering digunakan oleh guru lebih kepada pemahaman umum dan tidak menyerlahkan maklumat yang terkandung dalam terminologi Matematik itu sendiri. Selain itu, strategi pemahaman frasa yang digunakan oleh para guru lebih kepada pemahaman umum dan tidak menyerlahkan maklumat kepada murid berkaitan subjek, arahan dan kata kunci dalam pengajaran Matematik berperkataan. Hal ini telah menyukarkan proses pemahaman istilah Matematik oleh murid dan secara tidak langsung mewujudkan kekaburan dalam memahami terminologi dan kemahiran prosedur Matematik.

Selain itu, strategi pemahaman bahasa yang melibatkan penggunaan struktur ayat amat tidak relevan di peringkat prasekolah kerana pada tahap umur 4 hingga 6 tahun ini mereka masih belum menguasai sepenuhnya kebolehan mentafsir ayat tersebut. Oleh itu, penggarapan maklumat dalam pengajaran Matematik berperkataan sukar dicapai, apatah lagi dalam mewujudkan kefahaman berkaitan istilah mengikut kemahiran prosedur dan terminologi awal Matematik. Grafin, Case dan Siegler (1994) menyatakan bahawa terdapat limitasi dalam peringkat perkembangan seorang kanak-kanak dalam aspek kognitif yang perlu dititikberatkan dalam usaha memperkenalkan golongan ini berkaitan sesuatu kemahiran. Keperluan menangani konflik kekaburan menggarap istilah mengikut terminologi dan kemahiran menguasai prosedur Matematik perlu dilakukan dengan mengambil kira keupayaan kognitif pada tahap umur kanak-kanak di samping mengaplikasikan kaedah pengajaran yang lebih efisien dalam pengajaran Matematik berperkataan.

Bertitik tolak daripada kajian ini, maka perlunya kajian lanjutan dilakukan dengan menghubungkaitkan disiplin bahasa dan disiplin Matematik agar pengajaran Matematik berperkataan didapati lebih berinternalisasi (bermaklumat) dan bermakna. Berteraskan Teori Prosodi Semantik yang akan dibangunkan dalam kajian ini diharapkan dapat menjadi medium penyelesaian dan bertindak sebagai strategi yang efektif dalam menangani kekaburan memahami 
konsep atau istilah awal Matematik mengikut kemahiran prosedur dan terminologinya.

Matematik memiliki falsafah khas yang tiada dalam bidang lain walaupun bidang Sains. Konsep-konsep asas yang terdapat dalam bidang Matematik seperti bentuk, hubungan, kelas, ketakterhinggaan, sifar, sama dan ketaksamaan ini memerlukan kefahaman falsafah untuk memahami konsep-konsep ini dengan lebih mendalam. Ilmu Matematik ini sangat penting untuk dipelajari disebabkan ilmu ini menjadi 'penghubung' antara metafizik dengan bidang-bidang ilmu Sains yang lain (Samian, 1997). Ilmu Matematik sangat penting dipelajari keran ilmu ini memberi penekanan kepada kemahiran menyelesaikan masalah yang merangkumi proses penyelesaian masalah seperti memahami masalah, merancang strategi, melaksanakan rancangan dan menyemak kesudahannya (Yayaha \& Elanggovan, 2010). Menurut Smith (1953), kalendar Maya purba yang menggunakan simbol untuk menandakan kuantiti telah digunakan sejak tahun 3000 SM. Justeru, apabila sampai ke zaman Plato dan Aristotle pada tahun 400 hingga 350 SM, Matematik telah berkembang menjadi bidang pengajian.

Menurut Shaharir (2010), sitasi terhadap teori Matematik tidak tersekat pada nombor dan geometri sahaja. Pandangan ini mengungkapkan persepsi dalam bidang Matematik yang bukan hanya ditanggapi dalam perspektif hukum dan ilmu Matematik sahaja, malah perlu diperluas dan diamati dalam hal sosial. Menurutnya lagi, ahli Matematik moden bukan sekadar seorang pengkhusus yang sempit dalam jurusannya yang tidak menyedari tentang kehidupan kecendekiawanannya (intelektual). Kebiasaannya, ahli Matematik tidak suka mempamerkan kebolehannya dan selalu kekurangan dalam keupayaan forensik. Pandangan ini menjurus kepada sikap jumud ahli-ahli Matematik yang seringkali membiarkan deria kesuperiorannya dalam hal ehwal kecendekiawanan dan menutup mindanya dalam hal ehwal kemaraan yang lebih menarik dalam sains sosial. Menurutnya lagi, fenomena ini telahpun menutupi pemikiran ahli-ahi mantik yang menggagaskan ilmu Matematik itu kepada ilmu mantik (logik dan logika). Semua kajian mereka berasaskan andaian asas bahawa ilmu mantik yang mereka analisis bersifat mutlak dan tidak boleh dipertikaikan. Namun, apabila ilmu mantik ini ditemui oleh ahli antropologi, dan diperbahaskan mengenai kepentingan bidang ini dari sudut budaya, barulah ilmu ini berkembang kepada artifak budaya. 
Sebagai perbahasannya, memang tidak dapat dinafikan bahawa kemahiran prosedur seperti operasi Matematik ini seperti yang digagaskan oleh kumpulan ilmu mantik bersifat mutlak. Sebagai contoh, frasa seperti kebenaran Matematik, kepastian Matematik boleh ditemui dalam kalangan golongan Matematik, tetapi biasanya dengan syarat yang difahami umum seperti $2+2=4$, atau 2 biji epal dalam sebuah kotak ditambah dengan 2 biji epal lagi, akan menjadi 4 biji epal di dalam kotak tersebut. Akan tetapi, terdapat juga rumus Matematik yang gagal membukikan kebenarannya, misalnya rumus yang dihasilkan oleh ahli Matematik seperti Imre Lakators (1976), iaitu menerusi penghasilan rumus Euleran $b-r+m=2$ dengan " $b$ " bermaksud bilangan bucu polihedron, "r" bermaksud bilangan birainya dan " $m$ " bermaksud bilangan mukanya dan dalam satu siri beliau turut memberikan beberapa bukti mengenai hal itu setiap kali polihedron baharu muncul. Oleh itu, bukti dalam Matematik ditentukan oleh budaya (Shaharir, 2010). Perkara yang dibuktikan dalam satu generasi gagal mewakili generalisasi seterusnya sebagai satu piawai yang tegar.

Bidang Matematik tidak sekadar merupakan bidang logik atau mantik. Ini terbukti dalam banyak perdebatan berkaitan hal ini. Dalam banyak penelitian, terdapat banyak kajian yang mula menyedari akan hal ini. Hal ini kerana bidang Matematik memiliki andaian tersembunyi yang perlu dibahaskan atau dibincangkan oleh ahliahli Matematik dan terpaksa menolak andaian generasi terdahulu (Shaharir, 2010). Kemuncak perbahasan ini apabila pemenang Hadiah Nobel, Eugene P. Wigner menggungkapkan satu gagasan yang menyentuh wujudnya hubungan yang tersembunyi dalam sains tabii. Hal ini merujuk apabila seseorang ahli fizik Matematik kehilangan punca bagi konsep atau pendekatan baharu, selalunya merujuk kepada Matematik untuk dijadikan sebagai petunjuk. Kesemua ini merupakan inti pati pening dalam usaha mewujudkan penerapan budaya dalam bidang-bidang Matematik. Dengan kata lain, Matematik dan fizik saling bertimbal balik. Bidang-bidang lain juga telah mula menyerap dalam bidang Matematik, misalnya muzik dan kejuruteraan. Menurut Stanic et al. (1992), terdapat dua disiplin ilmu yang mempunyai pengaruh yang besar ke atas pendidikan Matematik, iaitu disiplin Matematik dan disiplin psikologi. Pakar Matematik berminat terhadap pengajaran dan pembelajaran Matematik. Ketidakmampuan sebahagian pelajar yang memasuki 
universiti untuk mengikuti kursus Matematik pada peringkat rendah dan sederhana dengan jayanya telah mendorong pakar Matematik untuk meneliti perkara yang dilakukan oleh sekolah.

Menurut Wilder (Shaharir, 2010), Matematik sebagai satu peranti budaya yang dicipta oleh manusia untuk kegunaan menyesuai dan kepuasan akalnya. Kelebihan mengambil satu pandangan budayalogi Matematik bukan sahaja ditemui dalam perspektif yang dapat memberi kefahaman pelbagai falsafah Matematik dan raison d'etrenya, tetapi dalam pendekatan kuasa budaya yang mendominasi dan masih mengawal evolusi penciptaan Matematik (Shaharir, 2010). Menyentuh tentang hubungan Matematik dan budaya, kajian ini cuba memetik pandangan Wilder (1967) dan Crowe (1975) (Shaharir, 2010) mengenai Hukum Intuisi Budaya. Dalam gagasan hukum ini, wujud intuisi budaya yang membentuk pandangan asas yang diterima secara am berkaitan dengan konsepkonsep Matematik. Hukum ini diamati menerusi tabii budaya Matematik yang dilihat mengamalkan amalan mantik. Intuisi pula diamati menerusi kepercayaan Matematik yang terjelma dalam budaya penceritaan rakyat.

Intuisi ini mengandungi kepercayaan berkenaan dengan konsep Matematik asas yang didukungi tanpa soal oleh kebanyakan ahli Matematik. Setiap bidang Matematik mengembangkan intuisi kolektifnya oleh pengamal kolektifnya. Menyoroti hukum ini, kajian ini terpanggil untuk mengamati pandangan pengamal kolektif tentang konsep-konsep Matematik yang dijelmakan dalam pengajaran, khususnya dalam bidang pengajaran menerusi medium bahasa. Dalam konteks ini, bahasa yang digunakan dalam pengajaran Matematik membantu dalam menjelmakan konsep-konsep Matematik. Untuk mencapai matlamat ini, maka proses pembelajaran dan pengajaran Matematik di sekolah perlu ditingkatkan (Mohd Faizal Nizam Lee dan Tze, 2017)

Dalam kajian ini, konsep-konsep Matematik merujuk kepada kemahiran prosedur, iaitu operasi atau formula Matematik, manakala terminologi merujuk kepada kupasan atau penghuraian berkaitan operasi atau formula Matematik tersebut. Ruang lingkup bidang Matematik difokuskan kepada konsep awal Matematik yang diajar kepada kanak-kanak yang berumur 4 tahun. 


\section{Analisis Konsep Awal Matematik Menerusi Teori Prosodi Semantik}

Teori Prosodi dibangunkan oleh Firth (1957), yang merujuk kepada tingkah laku kata. Konsep ini diperkukuhkan oleh Louw (1993) yang menyifatkan bahawa prosodi semantik ialah aura makna yang konsisten dengan kolokasinya (Louw, 1993: 157) dalam penyataan berikut;

Semantic Prosody with several examples such as the adverbs utterly, the phrase bent on and the expressio.

(Louw, 1993:157)

Seterusnya, Sinclair (1996) mentakrifkan Prosodi Semantik sebagai pilihan leksikal yang berfungsi menghubungkan makna dengan maksud. Menurut Sinclair, prosodi semantik ialah;

Attitudinal and on the pragmatic side of the semantics-pragmatics continuum. The right SP is bound to express the attitudes of speakers/ writers and their purpose with harmony and explicitness.

(Sinclair, 1996: 87)

Oleh itu, berdasarkan pandangan ini dapat dirumuskan bahawa Teori Prosodi Semantik ialah satu metodologi penelitian leksikal bagi melihat konteks keberadaan atau gabungan kata yang membawa makna tertentu dan menonjolkan aura makna yang konsisten. Pemanfaatan Teori Prosodi Semantik dalam kajian ini dilakukan menerusi analisis kolokasi terhadap korpus (data diperoleh daripada Pangkalan Data Korpus Dewan Bahasa dan Pustaka -DBP) berkaitan makna leksikal padan/padanan, kumpul, mengasingkan dan banding. Data korpus merupakan data sebenar pengguna bahasa Melayu dan dapat memperlihatkan konteks sebenar penggunaan bahasa penutur (Hashim et al., 2012). Oleh itu, butiran kolokasi daripada data korpus ini akan diteliti konteksnya bagi memahami maksud yang terkandung dalam makna leksikal tersebut serta meneliti nilai leksikal. Hasil garapan makna terhadap leksikal tersebut akan menentukan konteks dan makna berkaitan konsep padan/padanan, kumpul, mengasingkan dan banding yang kemudiannya dapat menemukan kepelbagaian 
makna bagi konsep tersebut yang perlu didedahkan dengan tepat oleh guru kepada kanak-kanak agar kumpulan ini memahami dan dapat menterjemah konsep awal Matematik, iaitu padanan, kumpul, asing dan membanding dengan baik (Sarudin et al., 2019). Analisis juga menunjukkan nilai leksikal juga sering bersifat positif apabila perkataan tersebut (padan/padanan, kumpul, mengasingkan dan banding) berkolokasi dengan kata-kata yang bernilai positif. Pola bahasa yang terdapat dalam data korpus dapat menyatakan makna dengan tepat seperti yang dikendong oleh penuturnya (Sarudin \& Jalaluddin, 2015)

Berdasarkan pandangan dan proses tersebut, maka kajian ini akan memanfaatkan Teori Prosodi Semantik berasaskan kepada 3 fungsi, iaitu pemilihan item leksikal yang memenuhi logik dan peraturan tatabahasa, kedua pemilihan leksikal tidak berlaku sewenangwenangnya dan ketiga, kolokasi kata bertujuan komunikatif. Dari sudut analisis bahasa menggunakan Teori Prosodi Semantik, ilmu Matematik perlu dihayati secara mendalam dari sudut makna dalam konsep-konsep yang disampaikan oleh guru dengan memfokuskan paradigma multikonteks yang diterapkan dalam kajian ini melalui (1) Pengayaan pengetahuan, (2) Berfikiran kreatif, (3) Pendekatan semantik dan pragmatik dan (4) Motivasi kendiri.

Melalui rangkuman keempat-empat elemen ini, pembelajaran dan pemudahcaraan oleh para guru dan kanak-kanak di Pusat Anak Permata Negara dapat dilaksanakan dengan berkesan. Prinsip berperkataan yang konsisten ini menjadikan pembelajaran dan pemudahcaraan oleh guru-guru dan kanak-kanak awal berkaitan kemahiran prosedur dan terminologi awal Matematik menjadi lebih bermakna dengan menekankan beberapa proses, iaitu (1) Pilihan perkataan atau leksis yang digunakan oleh guru dan kanak-kanak dalam pengajaran kemahiran prosedur dan terminologi Matematik (2) Fungsi perkataan (3) Tujuan komunikasi yang menyentuh tentang sifat perkataan dalam menyerlahkan kemahiran pnrosedur dan terminologi awal Matematik. Ketiga-tiga proses ini memastikan guru-guru dan kanak-kanak dapat menggunakan perkataan berkolokasi dengan tepat dalam menyerlahkan konsep-konsep awal 
matematik menerusi pemahaman berkaitan kemahiran prosedur dan terminologi awal Matematik.

Dapatan kajian ini diharap boleh memenuhi aspirasi pendidikan secara keseluruhan dengan memenuhi ciri eksais, kualiti, ekuiti, perpaduan dan kecekapan aspirasi murid sebagai individu dengan memenuhi ciri berpengetahuan, menguasai kemahiran berfikir, boleh memimpin, memperkaya penguasaan bahasa, memupuk etika dan kerohanian serta menyerlahkan identiti nasional. Hal ini demikian kerana, elemen bahasa telah menjadi medium pengajaran awal Matematik kepada semua kanak-kanak normal di samping menggagaskan pengajaran bermakna dengan menerapkan kemahiran berfikir dalam menyerlahkan terminologi dan prosedur awal Matematik melalui pilihan perkataan yang digunakan oleh guruguru dan kanak-kanak dalam pembelajaran dan pemudahcaraan awal Matematik ini.

\section{Kemahiran Prosedur}

Istilah kemahiran prosedur bermaksud suatu kecekapan dalam menghasilkan sesuatu mengikut aturan yang telah ditetapkan. Dalam bidang Matematik, kemahiran prosedur merujuk kepada kebolehan memahami operasi dan formula Matematik yang mengandungi proses penyelesaian masalah Matematik. Menurut Hussin (2014), sehubungan itu, pemahaman terhadap proses penyelesaian masalah ini merujuk kepada kemahiran memahami komunikasi dalam Matematik merupakan salah satu aspek yang diberi penekanan dalam kurikulum Matematik di seluruh dunia. Beliau memetik gagasan NCTM (2000) yang mengharapkan pendidikan Matematik berupaya melahirkan murid yang mampu menganalisis, menilai dan berkomunikasi dengan menggunakan bahasa Matematik (dalam kajian ini disifatkan sebagai operasi/ kemahiran prosedur Matematik) yang tepat untuk menggambarkan idea, pemikiran dan strategi Matematik mereka dengan teratur kepada rakan dan guru.

\section{Terminologi Matematik}

Matematik ditakrifkan sebagai ilmu yang berteraskan mantik, kajian ke atas nombor, saiz dan rupa bentuk dan hubungan antaranya. Selain 
itu, Matematik juga ditakrifkan sebagai perihal bukti dan perihal yang boleh dibina melalui teori set. Di samping itu, Matematik dikatakan sebagai sejenis ilmu pengetahuan mengenai nombor, bentuk, susunan, hubungan dan lain-lain dengan menggunakan simbol. Ilmu Matematik sebagai sains unggul bagi kelaratan semesta yang khusus; sains permodelan fenomena, masalah dan sebagainya serta penyelesaiannya; sains unggul bagi operasi-operasi biasa yang dilakukan ke atas benda-benda alam persekitaran dan pemikiran (Samian, 1997). Rangkumannya, terminologi Matematik ialah suatu kajian tentang istilah yang berkaitan dengan penggunan simbol dan angka.

Menurut Puteri Roslina (2005), terminologi ialah pengajian dan bidang aktiviti yang memberi tumpuan kepada pengumpulan, penghuraian, pemprosesan dan penyampaian istilah, iaitu butir leksikal milik penggunaan yang khusus dalam satu atau beberapa bahasa. Tambahnya lagi, dari segi matlamat, terminologi merupakan ahli keluarga bidang leksikografi yang menggabungkan dua matlamat, iaitu pengumpulan data tentang leksikon suatu bahasa dengan memberikan maklumat dan kadang-kadang nasihat dan perkhidmatan kepada pengguna bahasa. Menurut Samian (1997), dalam bahasa Inggeris, istilah Mathematics itu berasal daripada bahasa Latin, iaitu Mathematicus. Mathematicus dalam bahasa Latin berakar umbi kepada bahasa Yunani Mathematikos. Mathematikos ini berpunca daripada istilah manthanein yang bermaksud mempelajari. Istilah ini juga bermaksud menumpukan perhatian sepenuhnya. Di samping itu, maksudnya menjurus kepada ketepatan yang jitu dan keyakinan. Menurut beliau, ilmu yang dikatakan Matematik itu bersifat kejituan yang pasti. Oleh itu, dalam konteks kajian ini, terminologi awal Matematik merujuk kepada proses meghuraikan istilah yang terkandung dalam konsep-konsep Matematik.

\section{OBJEKTIF KAJIAN}

a) Mengenal pasti pedagogi guru dalam pengajaran awal Matematik bagi menjelaskan kekaburan konsep mengikut kemahiran prosedur dan terminologi terhadap kanak-kanak. 
b) Mengenal pasti sejauh manakah pendekatan leksis berdasarkan Teori Prosodi Semantik dapat menjelaskan kekaburan konsep mengikut terminologi dan kemahiran prosedur melalui PdPc awal Matematik oleh guru dan kanak-kanak.

\section{METODOLOGI KAJIAN}

\section{Responden Kajian}

Kajian ini dijalankan di empat buah sekolah yang terpilih di sekitar negeri Perak, iaitu Pusat Anak PERMATA Negara Sungai Siput, Pusat Anak PERMATA Negara Teluk Intan, Pusat Anak PERMATA Negara Besout 1, dan Pusat Anak PERMATA Negara Bercham yang melibatkan 20 orang guru dan 60 orang kanakkanak. Daripada jumlah guru ini, 8 orang daripadanya terlibat dalam proses pencerapan PdPc. Oleh sebab kajian ini ingin mengenal pasti pemahaman dalam aspek kemahiran prosedur dan terminologi awal Matematik dalam kalangan guru dan kanak-kanak awal, maka kajian ini hanya berfokus kepada pengajaran dan pembelajaran awal Matematik di sekolah tersebut melibatkan konsep padanan, kumpul, asing dan membanding.

\section{Instrumen Kajian}

Menurut Yahaya, Hashim, Ramli, Boon, dan Hamdan (2007), instrumen yang dipilih hendaklah mempunyai ukuran yang sah, sahih dan dapat digunakan oleh pengkaji. Kajian ini menggunakan soal selidik dan senarai semak pencerapan PdPc.

\section{Soal Selidik}

Instrumen dalam kajian ini menggunakan instrumen soal selidik yang dibina bagi mengumpul data yang diperlukan. Menurut Sabitha (2006), data dan maklumat yang diperoleh melalui soal selidik adalah tepat dan kaedah ini juga dapat menjimatkan kos, masa dan senang mendapat kerjasama daripada responden serta dapat menghasilkan item-item yang konsisten dan boleh dipercayai. Menurut Sekaran dan Bougie (2016), soal selidik ialah cara yang sesuai untuk mengumpulkan data kerana ia mudah untuk diuruskan, menjimatkan masa dan memudahkan langkah pemprosesan. Bagi kajian ini, penyelidik telah membahagikan soal selidik kepada dua 
bahagian, iaitu bahagian I, Latar Belakang Responden dan bahagian II, Inventori Profesionalisme Pendidik (Guru). Berikut merupakan soal selidik bahagian A yang terdiri daripada Latar Belakang Responden.

Soal selidik dibangunkan untuk mengukur kefahaman guru-guru terhadap konsep mengikut kemahiran prosedur dan terminologi awal Matematik. Soal selidik ini dibina dan dirujuk kepada dua orang pakar dalam bidang Matematik.

\section{Senarai Semak Pencerapan PdPc}

Pencerapan merupakan suatu proses bagi mengenal pasti serta mengukur kesan set olahan pemboleh ubah bukan bersandar kepada pemboleh ubah bersandar. Pencerapan ini melibatkan pengukuran terhadap kedua-dua pemboleh ubah berkenaan, iaitu bersandar dan tidak bersandar. Definisi ini tidak jauh berbeza dengan pandangan Konting (2005), yang menganggap pencerapan pengajaran sebagai suatu proses membantu perkembangan profesional guru dengan memberi maklum balas tentang interaksi bilik darjah dan menolong guru mengajar dengan lebih berkesan. Pengajaran disifatkan juga sebagai satu sistem tingkah laku yang direka khusus oleh sesebuah organisasi untuk mempengaruhi tingkah laku pengajaran demi meningkatkan tahap pembelajaran murid. Dalam konteks kajian ini, pengkaji melakukan pencerapan terhadap 8 orang guru di PAPN di empat buah sekolah yang terpilih di sekitar negeri Perak, iaitu PAPN Sungai Siput, PAPN Teluk Intan, PAPN BESOUT 1, dan PAPN Bercham. Walaupun responden yang terlibat dalam kajian ini ialah seramai 20 orang, namun mereka hanya terlibat dalam pengisian soal selidik. Hanya seramai 8 orang guru sahaja yang dicerap dalam pemantauan PdPc. Proses pencerapan dilakukan melalui penelitian secara senarai semak dalam bentuk jadual sinonim pengajaran berkaitan konsep Matematik. Kandungan senarai semak PdPc juga melalui proses penilaian oleh pakar bidang bagi memastikan kesahan kandungannya. Teknik ini telah digunakan oleh Jinks dan Morgan (1999) dalam kajiannya untuk membuat pengesahan dari sudut isi kandungan.

\section{Pelaksanaan Pedagogi guru dalam PdPc Awal Matematik}

Dalam konteks pendidikan Matematik, khususnya, para guru, penyelidik mahupun pengamal bidang sentiasa peka kepada 
perkembangan bidang ini dari sudut ilmu pengetahuannya. Berdasarkan National Association for the Education of Young Children (NAEYC) and the National Council of Teachers of Mathematics (NCTM) pada tahun 2002-dikemas kini pada tahun 2010 telah mencadangkan penyelidikan yang praktis dapat dilakukan dalam meneliti program awal kanak-kanak. Begitu juga pertubuhan National Research Council's Committee on Early Childhood Mathematics yang mencadangkan agar penyelidikan menumpukan terhadap pembelajaran, pengajaran, pendidikan guru, dan kurikulum (Cross, Woods, \& Schweingruber, 2009). Laporan ini menunjukkan bahawa perlunya penambahbaikan dalam pengajaran awal Matematik agar memenuhi pembelajaran berkualiti tinggi dan bertambah baik. Hal ini meliputi persediaan guru dan latihan untuk menyediakan semua kanak-kanak dengan asas Matematik untuk persediaan ke sekolah rendah dan seterusnya. Penyelesaian kepada fenomena ini ditangani dengan menyediakan pembelajaran Matematik yang memenuhi piawaian Matematik di peringkat awal serta menyediakan kanak-kanak untuk memenuhi standard pembelajaran Matematik pada tahap umur mereka. Oleh itu, dalam kajian ini, penyelidik meneliti hal ini dengan menyediakan soal selidik berkaitan kemahiran pelaksanaan pedagogi guru berkaitan konsep awal Matematik.

Berikut merupakan item-item dalam soal selidik yang diteliti berkaitan konsep awal Matematik dan memberi pilihan kemahiran sama ada secara kemahiran operasi, kemahiran terminologi dan kemahiran berkonteks.

Jadual 1

Pembahagian Item Soal Selidik Mengikut Inventori Profesionalisme Pendidik (Guru).

\begin{tabular}{|c|c|c|c|c|}
\hline \multirow{2}{*}{ Bil. } & \multirow{2}{*}{ Perkara } & \multicolumn{3}{|c|}{ KEMAHIRAN } \\
\hline & & Operasi & Terminologi & Konteks \\
\hline \multirow[t]{2}{*}{ A) } & PADANAN & & & \\
\hline & $\begin{array}{l}\text { Memadankan gambar dengan } \\
\text { kegunaannya }\end{array}$ & & & \\
\hline i) & Memilih objek & & & \\
\hline ii) & Mengenal pasti jenis objek & & & \\
\hline
\end{tabular}




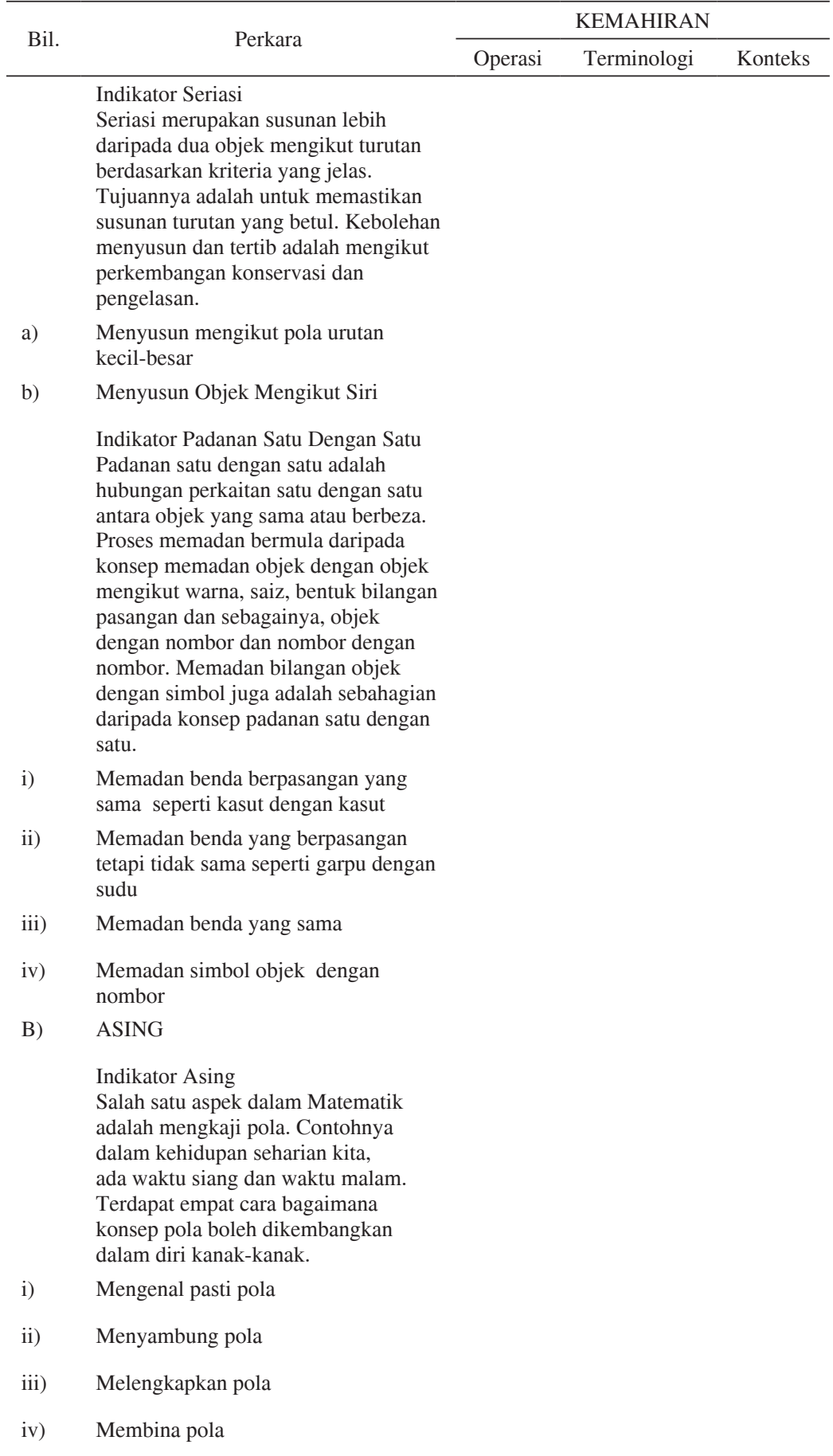




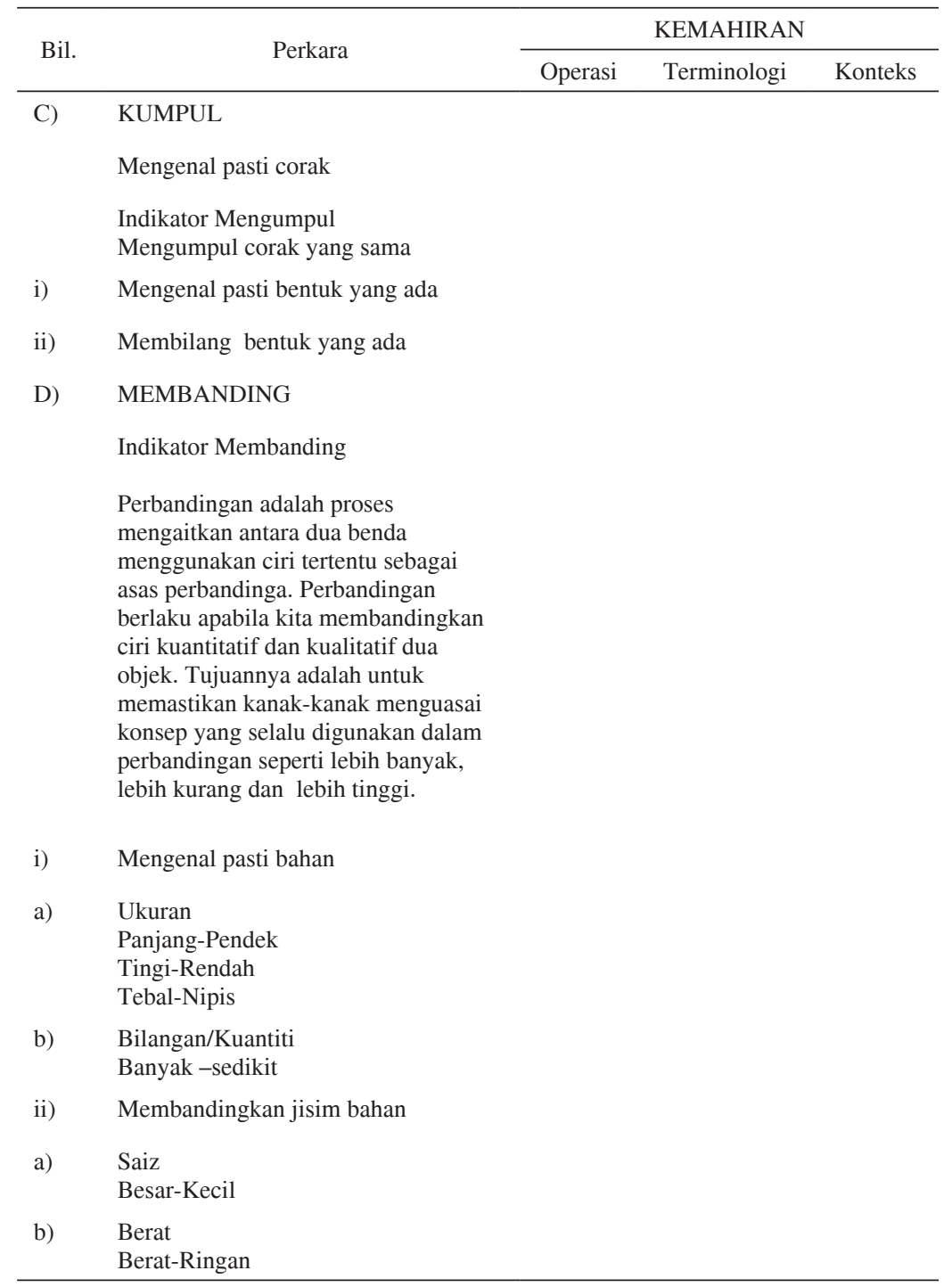

Hasil daripada analisis soal selidik, dapatan penyelidikan yang menerangkan Objektif 1 ialah seperti berikut;

\section{Pusat Anak PERMATA Negara, Besout 1}

Terdapat 3 soal selidik yang diedarkan kepada 3 orang responden di PAPN Besout 1. Analisis pedadogogi yang berkaitan kemahiran pedagogi awal Matematik bagi konsep padanan, kumpul, asing 
dan membanding telah dideskripsikan. Dalam semua bahagian, hasil kajian mendapati bahawa ketiga-tiga responden menandakan hampir keseluruhan bagi kemahiran operasi, terminologi dan konteks. Bagi setiap soal selidik tersebut, responden-responden tersebut menandakan semua kemahiran tersebut untuk item memilih objek, mengenal pasti jenis objek, menyusun mengikut pola urutan kecil-besar, menyusun objek mengikut siri, memadan benda berpasangan yang sama seperti kasut dengan kasut, memadan benda yang berpasangan tetapi tidak sama seperti garpu dengan sudu, memadan benda yang sama, dan memadan simbol objek dengan motor. Bahagian kumpul juga menunjukkan hasil kajian yang sama, iaitu responden menanda ketiga-tiga bentuk kemahiran pedagogi awal Matematik, iaitu secara operasi, terminologi dan konteks bagi mengumpul corak yang sama, mengenal pasti bentuk yang ada dan membilang bentuk yang ada Bagi indikator asing pula, setiap responden turut menandakan semua jenis kemahiran tersebut, iaitu mengenal pasti pola, menyambung pola, melengkapkan pola dan membina pola. Di samping itu, hasil kajian mendapati bahawa bagi indikator membanding setiap responden turut menandakan ketigatiga bentuk kemahiran tersebut untuk mengenal pasti bahan, ukuran, bilangan/kuantiti, membandingkan jisim bahan, saiz dan berat.

\section{Pusat Anak PERMATA Negara, Bercham}

Terdapat 6 responden terlibat dalam pengisian soal selidik yang telah diedarkan di PAPN Bercham. Bagi indikator padanan terdapat responden 1 yang menandakan kemahiran konteks bagi item memadankan gambar dengan kegunaannya, kemahiran terminologi dan kemahiran konteks bagi memilih objek, kemahiran terminologi bagi menyusun mengikut pola urutan kecil-besar, kemahiran terminologi untuk menyusun objek mengikut siri, kemahiran terminologi untuk memadan benda berpasangan yang sama seperti kasut dengan kasut, kemahiran konteks untuk memadan benda yang berpasangan tetapi tidak sama seperti garpu dengan sudu, kemahiran terminologi untuk memadan benda yang sama dan kemahiran konteks untuk memadan simbol objek dengan nombor. Bagi indikator asing, hasil kajian mendapati responden 1 menandakan kedua-dua bahagian untuk kemahiran operasi dan kemahiran terminologi, manakala untuk indikator membanding responden 1 menandakan kedua-dua bahagian bagi kemahiran terminologi dan kemahiran konteks 
Bagi soal selidik kedua, hasil kajian mendapati bahawa responden 2 cenderung untuk memilih kemahiran terminologi dan kemahiran konteks untuk indikator padanan. Hal ini membuktikan bahawa responden 2 lebih menggunakan kedua-dua kemahiran ini dalam melakukan aktiviti padanan. Selain itu, indikator asing, kumpul dan membanding turut menunjukkan hasil kajian yang sama apabila responden 2 menandakan kemahiran terminologi dan kemahiran konteks. Maka, dapat dirumuskan bahawa responden 2 lebih cenderung menggunakan kemahiran terminologi dan kemahiran konteks dalam menerangkan konsep-konsep awal Matematik.

Bagi soal selidik ketiga, hasil kajian mendapati responden 3 menandakan ketiga-tiga kemahiran bagi setiap indikator yang ada. Hal ini membuktikan bahawa responden 3 menggunakan kemahiran operasi, terminologi dan konteks dalam pedagogi awal Matematik. Di samping itu, soal selidik keempat juga menunjukkan hasil kajian yang sama apabila responden 4 cenderung menggunakan ketiga-tiga kemahiran untuk indikator padanan, asing, kumpul dan membanding. Sebagai contohnya, indikator padanan satu dengan satu menunjukkan penglibatan ketiga-tiga kemahiran yang memadan benda berpasangan yang sama, memadan benda yang berpasangan tetapi tidak sama, memadan benda yang sama dan memadan simbol objek dengan nombor.

Bagi soal selidik kelima, hasil kajian mendapati bahawa responden 5 menggunakan kemahiran operasi dan kemahiran terminologi untuk indikator padanan. Begitu juga dengan indikator asing yang menunjukkan penggunaan kemahiran operasi dan kemahiran terminologi. Hanya kemahiran konteks digunakan dalam melengkap dan membina pola. Bagi indikator kumpul, responden menunjukkan penggunaan kemahiran operasi dan terminologi untuk mengumpul corak yang sama, mengenal pasti bentuk yang ada dan membilang bentuk yang ada, manakala untuk indikator membanding, responden cenderung menggunakan ketiga-ketiga kemahiran.

Bagi soal selidik seterusnya, indikator padanan menunjukkan responden 6 cenderung menggunakan kemahiran terminologi dan kemahiran konteks, manakala untuk indikator asing, kumpul dan membanding responden cenderung menggunakan kemahiran terminologi dan kemahiran konteks. 


\section{Pusat Anak PERMATA Negara, Teluk Intan}

Terdapat 5 soal selidik yang telah diedarkan kepada PAPN Teluk Intan bagi mengenal pasti kemahiran pedagogi awal Matematik PAPN Teluk Intan. Bagi responden 1, hasil analisis soal selidik menunjukkan bahawa terdapat penggunaan kemahiran operasi dan kemahiran terminologi dalam indikator padanan. Sebagai contohnya, responden menggunakan kedua-dua kemahiran tersebut dalam melakukan susunan lebih daripada dua objek mengikut turutan berdasarkan kriteria, menyusun mengikut pola urutan kecilbesar dan padanan satu dengan satu manakala untuk memadan benda berpasangan yang sama, memadan benda berpasangan tetapi tidak sama, memadan benda yang sama dan memadan simbol objek dengan nombor menunjukkan penglibatan ketiga-tiga kemahiran. Bagi indikator asing dan kumpul, hasil kajian menunjukkan bahawa penggunaan kemahiran operasi dan terminologi sahaja, manakala indikator membanding menunjukkan penggunaan ketiga-tiga kemahiran.

Bagi responden 2, keseluruhan soal selidik menunjukkan responden menggunakan ketiga-tiga kemahiran dalam indikator padanan, asing, kumpul dan membanding.

Seterusnya, responden 3 menunjukkan hasil kajian keseluruhan, iaitu responden cenderung memilih kemahiran operasi dan kemahiran terminologi bagi indikator padanan, asing dan kumpul manakala indikator membanding, responden cenderung menggunakan ketigatiga kemahiran.

Seterusnya, responden 4, memilih penggunaan ketiga-tiga kemahiran dalam indikator padanan, kumpul dan membanding, manakala dalam indikator kumpul responden tidak memilih sebarang kemahiran (tidak berjawab).

Bagi soal selidik selanjutnya, analisis menunjukkan bahawa responden 5 memilih kemahiran operasi dan kemahiran terminologi sahaja untuk indikator padanan, asing, kumpul dan membanding. Responden menggunakan kedua-dua kemahiran ini untuk indikator seriasi, indikator padanan satu dengan satu, indikator asing, indikator kumpul dan indikator membanding yang di bawahnya terbahagi kepada perkara-perkara yang berkaitan. 


\section{Pusat Anak PERMATA Negara, Sg Siput}

Terdapat enam soal selidik yang telah diedarkan kepada PAPN $\mathrm{Sg}$ Siput. Responden menandakan indikator padanan dengan menggunakan kemahiran operasi berbanding kemahiran lain, iaitu menggunakan kemahiran operasi dalam memilih objek, mengenal pasti jenis objek, menyusun mengikut pola urutan kecil-besar, menyusun objek mengikut siri, memadan benda berpasangan yang sama, memadan benda yang berpasangan tetapi tidak sama, memadan benda yang sama dan memadan simbol objek dengan nombor. Untuk indikator asing, responden 1 tidak menandakan sebarang kemahiran dan indikator mengumpul pula responden cenderung menggunakan kemahiran operasi dan kemahiran terminologi sahaja. Selain itu, indikator membanding turut menunjukkan responden cenderung menggunakan kemahiran operasi dan kemahiran terminologi dalam mengenal pasti bahan dan membandingkan jisim bahan.

Bagi soal selidik selanjutnya melibatkan responden 2, hasil kajian mendapati bahawa responden 2 cenderung menggunakan kemahiran operasi dan kemahiran terminologi bagi semua indikator yang wujud.

Bagi soal selidik ketiga dan keempat, hasil kajian mendapati responden 3 dan responden 4 cenderung menggunakan ketigatiga kemahiran, iaitu kemahiran operasi, kemahiran terminologi dan kemahiran konteks untuk indikator padanan, asing, kumpul dan membanding. Responden 4 juga menandakan indikator asing dengan penggunaan ketiga-tiga kemahiran.

Bagi responden 5, hasil kajian mendapati bahawa responden cenderung menggunakan kemahiran operasi dalam indikator padanan, iaitu menggunakan kemahiran operasi dalam memilih objek, mengenal pasti jenis objek, indikator seriasi, menyusun mengikut pola urutan kecil-besar, memadan benda berpasangan yang sama seperti kasut dengan kasut, memadan benda yang berpasangan tetapi tidak sama seperti garpu dengan sudu, memadan benda yang sama dan memadan simbol objek dengan nombor. Bagi indikator asing, responden 5 memilih untuk tidak menandakan mana-mana pilihan pengguaan kemahiran. Bagi indikator kumpul, responden 5 menggunakan kemahiran terminologi untuk mengenal pasti bentuk yang ada dan membilang bentuk yang ada, manakala untuk indikator 
membanding, kemahiran operasi digunakan untuk ukuran bahan, bilangan bahan, saiz dan berat bahan.

Bagi soal selidik selanjutnya, responden 6 cenderung menggunakan kemahiran operasi dan kemahiran konteks dalam indikator padanan, manakala untuk indikator asing, responden 6 lebih menggunakan kemahiran operasi dan kemahiran terminologi. Untuk indikator kumpul, responden 6 menggunakan kemahiran operasi dan kemahiran konteks untuk mengenal pasti bentuk yang ada dan menggunakan ketiga-tiga kemahiran untuk membilang bentuk yang ada. Untuk indikator membanding, responden 6 memilih kemahiran operasi dan kemahiran konteks bagi item ukuran bahan, bilangan bahan dan membanding jisim bahan seperti saiz dan berat bahan.

\section{Refleksi Pencerapan PdPc berkaitan Kekaburan Kemahiran Prosedur dan Terminologi Awal Matematik}

Berdasarkan analisis pencerapan PdPc, iaitu yang hanya melibatkan 8 orang guru, penyelidik mendapati bahawa terdapat frasa-frasa sinonim digunakan dalam pengajaran berkaitan konsep-konsep awal Matematik bagi menjelaskan kekaburan kemahiran prosedur dan terminologi awal Matematik berikut;

Proses pembahagian pengajaran awal Matematik bagi konsepkonsep padanan, kumpul, asing dan banding telah dibahagikan kepada PAPN yang berbeza seperti berikut;

Jadual 2

Pengagihan Pengajaran Konsep Berdasarkan Lokasi PAPN

\begin{tabular}{clll}
\hline Bil & Pusat PERMATA Anak Negara & & Perkara \\
\hline 1 & Besout 1 & Asing & \\
2 & Bercham & Padanan & \\
3 & Sg Siput & Kumpul \\
4 & Teluk Intan & Membanding & \\
\hline
\end{tabular}

Hal analisis pencerapan PdPc di lokasi kajian mendapati bahawa guru-guru mengajar kanak-kanak berkaitan konsep-konsep padanan, kumpul, asing dan membanding menerusi penggunaan frasa-frasa sinonim seperti yang ditunjukkan dalam Jadual 2. 


\section{Jadual 3}

Dapatan Pencerapan PdPc di Pusat Anak PERMATA Negara, Besout 1

\begin{tabular}{|c|c|c|c|}
\hline Bil & Pusat Permata Anak Negara & Perkara & Sinonim \\
\hline 1 & Besout 1 & Asing & Cuba kita kira \\
\hline 2 & & & Ini warna apa? \\
\hline 3 & & & Ini bendera apa? \\
\hline 4 & & & Ini apa? \\
\hline 5 & & & Jom kita kira \\
\hline 6 & & & Mana bendera Malaysia \\
\hline 7 & & & Mana bendera Perak \\
\hline 8 & & & Masuk dalam ini \\
\hline 9 & & & Ambil bendera \\
\hline 10 & & & Cari bendera mana \\
\hline
\end{tabular}

Jadual 4

Dapatan Pencerapan PdPc di Pusat Anak PERMATA Negara Bercham

\begin{tabular}{|c|c|c|c|}
\hline Bil & Pusat Permata Anak Negara & Perkara & Sinonim \\
\hline 1 & Bercham & Padanan & Dengan \\
\hline 2 & & & Pasangan \\
\hline 3 & & & Tarik \\
\hline 4 & & & Cari warna yang sama \\
\hline 5 & & & Pilih \\
\hline 6 & & & Sama tak bentuk? \\
\hline
\end{tabular}

\section{Jadual 5}

Dapatan Pencerapan PdPc di Pusat Anak PERMATA Negara Sg. Siput

\begin{tabular}{ccll}
\hline Bil & Pusat Permata Anak Negara & Perkara & \multicolumn{1}{c}{ Sinonim } \\
\hline 1 & Sg Siput & Kumpul & Ikut warna yang sama \\
2 & & & Ambil semua \\
\hline
\end{tabular}


Jadual 6

Dapatan Pencerapan PdPc di Pusat Anak PERMATA Negara Teluk Intan

\begin{tabular}{|c|c|c|c|}
\hline Bil & $\begin{array}{c}\text { Pusat Permata Anak } \\
\text { Negara }\end{array}$ & Perkara & Sinonim \\
\hline 1 & Teluk Intan & membanding & Membezakan \\
\hline 2 & & & Tenggelam ke timbul \\
\hline 3 & & & Duduk bawah ke duduk atas? \\
\hline 4 & & & Turun ke naik \\
\hline 5 & & & $\begin{array}{l}\text { Yang mana penuh yang mana } \\
\text { kosong? }\end{array}$ \\
\hline 6 & & & Yang mana banyak yang mana sedikit \\
\hline 7 & & & Yang mana lebih yang mana kurang \\
\hline 8 & & & Satu bekas banyak satu bekas sedikit \\
\hline 9 & & & Air mana yang banyak? \\
\hline 10 & & & Besar kecil, tinggi rendah \\
\hline 11 & & & $\begin{array}{l}\text { Mana yang panjang dan mana yang } \\
\text { pendek? }\end{array}$ \\
\hline
\end{tabular}

Berdasarkan jadual-jadual tersebut, dapat diamati bahawa guruguru di PAPN tersebut menggunakan frasa-frasa dan leksikal yang bersinonim dengan makna konsep-konsep awal Matematik, iaitu padanan, kumpul, asing dan membanding. Taburan leksikal ini merupakan pengajaran sokongan yang memberi nilai tambah dan pengukuhan dalam pengajaran awal Matematik kepada kanak-kanak PAPN. Butiran lanjut dapat ditunjukkan dalam cerapan ekstrak transkripsi guru-guru PAPN di setiap lokasi kajian.

Kanak-kanak memahami konsep Matematik dengan cara yang menarik, tanpa bantuan orang dewasa. Kanak-kanak mudah mengembangkan ilmu Matematik setiap hari yang merangkumi pelbagai topik (contohnya, ruang, bentuk, corak, nombor, dan operasi) dan terdiri daripada beberapa ciri penting, iaitu minat, pemikiran konkrit dan abstrak, dan pemahaman dan salah faham (Ginsburg, Cannon, Eisenband, \& Pappas, 2006). Tambahan pula, bidang awal Matematik merupakan kecekapan yang perlu dipelajari untuk anak-anak lelaki dan perempuan pada peringkat prasekolah (Dowker, 2005). Hal ini demikian kerana kanak-kanak kecil mempunyai minat spontan dan kadang-kadang boleh atau 
mampu dalam melahirkan idea Matematik. Pemerhatian semula jadi telah menunjukkan bahawa apabila mereka diberi bentuk bongkah kanak-kanak kecil ini boleh membentuk pelbagai kreativiti seperti menentukan menara yang lebih tinggi daripada yang lain, mencipta dan memperluas corak yang menarik dengan blok, meneroka bentuk, mewujudkan simetri, dan sejenisnya (Seo \& Ginsburg, 2004). Hal ini menunjukkan bahawa pemikiran anak-anak bersifat konkrit dan abstrak.

Pengetahuan awal Matematik kanak-kanak bercirikan pemahaman. Walaupun mereka seolah-olah memahami idea asas berkaitan tambah dan penolakan pada awal, mereka gagal menyedari bahawa bentuk segitiga kelihatan ganjil (Clements, 1999). Ini bermakna walaupun pembelajaran awal Matematik semula jadi kanak-kanak sangat mengagumkan, adalah amat sukar untuk membangun pemikiran yang lebih komprehensif dan abstrak mengenai Matematik. Kanakkanak sering memerlukan lebih daripada pembelajaran semula jadi dan spontan mereka. Dengan kata lain, permainan tidak cukup untuk mengoptimumkan pembangunan Matematik kanak-kanak. Sebaliknya, mereka memerlukan pengajaran sokongan serta pengalaman pembelajaran yang mendedahkan mereka kepada konsep Matematik dengan progresif dan dimantapkan dengan pengetahuan semasa yang berkaitan dengan konsep-konsep Matematik yang dipelajarinya.

Terdapat pelbagai faktor yang berkaitan dengan pembelajaran awal Matematik dalam kalangan kanak-kanak. Hal ini termasuklah bahasa dan motivasi. Penyelidikan menekankan kepentingan bahasa dalam pemikiran Matematik (Rudd, Lambert, Satterwhite, \& Zaier, 2008). Kanak-kanak kecil bukan sahaja perlu memperoleh konsep awal Matematik menerusi kosa kata yang standard contohnya, katakata untuk kuantiti, seperti yang lebih besar atau kurang tetapi juga harus belajar cara menggunakan bahasa ini untuk menyatakan dan mewajarkan pemikiran awal Matematik mereka menerusi bentukbentuk bahasa yang tidak terhad. Dalam perkembangannya, kanak-kanak akan menjadi semakin sedar dengan pemikiran mereka sendiri dan mula menyatakannya dalam kata-kata mereka sendiri(Kuhn, 2000). Kemahiran metakognitif seperti ini diperlukan dalam pembelajaran awal Matematik sebagai perkembangan ilmu Matematik dalam kalangan kanak-kanak yang berumur 4 atau 5 tahun (Pappas, Ginsburg, \& Jiang, 2003). Oleh yang demikian, 
kajian ini meneliti sejauh mana pengajaran awal Matematik berasaskan leksikal mampu mencetuskan idea dan membangun pengetahuan yang lebih tinggi berasaskan konsep-konsep awal Matematik. Dalam konteks ini, penelitian konteks pengajaran guru penting untuk diamati dan diteliti bagi memperoleh pengetahuan berkaitan fenomena dan penyelidikan permasalahan yang timbul dalam pengajaran awal Matematik.

\section{Analisis Korpus Sebagai Metodologi Penelitian Gelagat Leksis bagi konsep 'padanan', 'kumpul', 'asing/mengasingkan' dan 'membanding'}

Bagi mengukuhkan perbincangan berkaitan objektif 2 , iaitu keperluan pengajaran awal Matematik didedahkan dengan pengajaran berasaskan leksikal, penyelidik meneliti kolokasi bagi kata padan/ padanan, kumpul, mengasingkan dan banding bagi memperlihat konteks yang tepat dengan terminologi tersebut. Leksikal padan diamati juga dalam aspek kolokasinya kerana penyelidik ingin meneliti kepelbagaian konteks yang dapat dianalisis daripada kolokasi yang terhasil. Begitu juga dalam leksikal mengasingkan, iaitu leksikal ini dipilih memandangkan kolokasi yang dapat diamati daripada leksikal asing tidak memperlihatkan taburan data yang berkualiti untuk diteliti, maka penyelidik memilih untuk meneliti perkataan mengasingkan bagi memperlihatkan data yang rencam dan gelagat yang boleh dianalisis. Hal yang sama juga dilakukan terhadap penelitian korpus bagi leksikal membanding. Analisis menerusi leksikal membanding tidak memperlihatkan gelagat kolokasi yang rencam, maka kajian ini memilih untuk meneliti konteks daripada leksikal banding. Konteks-konteks kolokasi daripada semua leksikal ini ini akan dapat membantu penyelidik mengamati perincian operasi dan terminologi awal Matematik yang seharusnya dinyatakan dengan tepat kepada kanak-kanak.

\section{Padan}

\begin{tabular}{cccccc}
\hline Korpus & $\begin{array}{c}\text { Istilah } \\
\text { Kiri }\end{array}$ & Kolokasi & $\begin{array}{c}\text { Istilah } \\
\text { Kanan }\end{array}$ & Kekerapan & Peratus (\%) \\
\hline $97949 \# 3$ & & padan & dengan & 25 & 35.7 \\
$96989 \# 0$ & sesuai & padan & & 6 & 8.57 \\
& & & & & (sambungan)
\end{tabular}




\begin{tabular}{|c|c|c|c|c|c|}
\hline Korpus & $\begin{array}{l}\text { Istilah } \\
\text { Kiri }\end{array}$ & Kolokasi & $\begin{array}{l}\text { Istilah } \\
\text { Kanan }\end{array}$ & Kekerapan & Peratus (\%) \\
\hline $97468 \# 1$ & & padan & $\begin{array}{c}\text { digabung- } \\
\text { kan }\end{array}$ & 2 & 2.85 \\
\hline 97796\#2 & memang & padan & & 3 & 4.28 \\
\hline 97807\#3 & $\begin{array}{l}\text { sama } \\
\text { padan }\end{array}$ & padan & & 6 & 8.57 \\
\hline 97883\#0 & & padan & sekali & 2 & 2.85 \\
\hline 97925\#1 & & padan & layak & 2 & 2.85 \\
\hline $60543 \# 0$ & & padan & $\begin{array}{c}\text { dengan } \\
\text { baju } \\
\text { labuh* }\end{array}$ & 1 & 1.42 \\
\hline 97889\#1 & tak & padan & & 15 & 21.4 \\
\hline 98221\#0 & & padan & lagi & 2 & 2.85 \\
\hline 97622\#0 & & padan & memadai & 1 & 1.42 \\
\hline 86448\#0 & & padan & ini & 2 & 2.85 \\
\hline 97962\#0 & $\begin{array}{l}\text { benar- } \\
\text { benar }\end{array}$ & padan & & 1 & 1.42 \\
\hline 97805\#1 & & padan & saja & 1 & 1.42 \\
\hline 97954\#9 & $\begin{array}{c}\text { pakaian- } \\
\text { nya }\end{array}$ & padan & & 1 & 1.42 \\
\hline
\end{tabular}

\section{Padanan}

\begin{tabular}{cccccc}
\hline Bil & $\begin{array}{c}\text { Istilah } \\
\text { Kiri }\end{array}$ & Kolokasi & Istilah Kanan & Kekerapan & $\begin{array}{c}\text { Peratus } \\
(\%)\end{array}$ \\
\hline $48254 \# 0$ & & padanan & yang tepat & 4 & 6.34 \\
$116956 \# 5$ & & padanan & yang sesuai & 7 & 11.1 \\
$97099 \# 0$ & & padanan & yang sama & 1 & 1.58 \\
$65008 \# 0$ & & padanan & dengan & 4 & 6.34 \\
$95280 \# 0$ & mengikut & padanan & & 1 & 1.58 \\
$97370 \# 0$ & & padanan & warna & 6 & 9.52 \\
$117075 \# 0$ & & padanan & ..tetapi.. & 2 & 3.17 \\
$118534 \# 1$ & & padanan & huruf & 4 & 6.34 \\
$116850 \# 8$ & & padanan & penggunaan & 5 & 7.93 \\
$11845 \# 2$ & merupakan & padanan & & 4 & 6.35 \\
$116837 \# 9$ & penggunaan & padanan & & 2 & 3.17 \\
& & & & & $($ sambungan $)$
\end{tabular}




\begin{tabular}{cccccc}
\hline Bil & $\begin{array}{c}\text { Istilah } \\
\text { Kiri }\end{array}$ & Kolokasi & Istilah Kanan & Kekerapan & $\begin{array}{c}\text { Peratus } \\
(\%)\end{array}$ \\
\hline $97557 \# 0$ & & padanan & pakaian & 6 & 9.52 \\
$114521 \# 0$ & & padanan & jelas & 2 & 3.17 \\
$97590 \# 0$ & dengan & padanan & & 9 & 14.3 \\
$117046 \# 39$ & & padanan & dan & 6 & 9.52 \\
\hline
\end{tabular}

\section{Kumpul}

\begin{tabular}{|c|c|c|c|c|c|}
\hline Bil & Istilah Kiri & Kolokasi & $\begin{array}{l}\text { Istilah } \\
\text { Kanan }\end{array}$ & Kekerapan & $\begin{array}{c}\text { Peratus } \\
(\%)\end{array}$ \\
\hline 97029\#0 & hasil & kumpul & & 1 & 1.61 \\
\hline 103782\#0 & & kumpul & duit & 16 & 25.8 \\
\hline 106772\#0 & & kumpul & jumlah & 2 & 3.22 \\
\hline 97712\#0 & & kumpul & semua & 3 & 4.84 \\
\hline $56467 \# 0$ & senarai & kumpul & & 2 & 3.22 \\
\hline 105942\#0 & & kumpul & $\begin{array}{l}\text { sebanyak } \\
\text { mungkin }\end{array}$ & 5 & 8.06 \\
\hline 97469\#0 & & kumpul & $\begin{array}{c}\text { hasil } \\
\text { gabungan }\end{array}$ & 1 & 1.61 \\
\hline $10433 \# 0$ & & kumpul & $\begin{array}{l}\text { dalam satu } \\
\text { bentuk }\end{array}$ & 1 & 1.61 \\
\hline 97835\#0 & & kumpul & $\begin{array}{l}\text { secuku- } \\
\text { pnya }\end{array}$ & 1 & 1.61 \\
\hline 97858\#0 & & kumpul & harta & 3 & 4.84 \\
\hline $97973 \# 0$ & & kumpul & orang & 6 & 9.67 \\
\hline $176 \# 0$ & pahala & kumpul & & 1 & 1.61 \\
\hline 97180\#0 & & kumpul & $\begin{array}{l}\text { belanja } \\
\text { sekolah }\end{array}$ & 1 & 1.61 \\
\hline $42811 \# 0$ & modal & kumpul & & 1 & 1.61 \\
\hline $97796 \# 3$ & & kumpul & $\begin{array}{c}\text { kuasa dan } \\
\text { nama }\end{array}$ & 2 & 3.22 \\
\hline 117620\#0 & & kumpul & tenaga & 3 & 4.84 \\
\hline $61283 \# 0$ & banyak & kumpul & & 6 & 9.67 \\
\hline 97401\#0 & & kumpul & maklumat & 3 & 4.84 \\
\hline 97456\#0 & & kumpul & barang & 4 & 6.45 \\
\hline
\end{tabular}




\section{Banding}

\begin{tabular}{cccccc}
\hline Bil & Istilah Kiri & Kolokasi & $\begin{array}{c}\text { Istilah } \\
\text { Kanan }\end{array}$ & Kekerapan & $\begin{array}{c}\text { Peratus } \\
(\%)\end{array}$ \\
\hline $118462 \# 2$ & membezakan & banding & & 4 & 8 \\
$108516 \# 0$ & & banding & tahun & 2 & 4 \\
$29324 \# 2$ & pulau & banding & & 13 & 26 \\
$109651 \# 1$ & & banding & nilainya & 2 & 4 \\
$97225 \# 1$ & proses kaji & banding & & 3 & 6 \\
$97765 \# 2$ & tiada tolok & banding & & 10 & 20 \\
$98023 \# 0$ & & banding & serta & 1 & 2 \\
$116866 \# 0$ & & banding & pada zaman & 3 & 6 \\
$97230 \# 1$ & & ini & 1 & 2 \\
$96625 \# 0$ & & banding & peratus & 1 & 10 \\
$100487 \# 0$ & & banding & dengan & 5 & 2 \\
$97282 \# 0$ & & banding & diri & 1 & 8 \\
$97794 \# 0$ & & banding & dan bezakan & 4 & 2 \\
\hline
\end{tabular}

\section{Mengasingkan}

\begin{tabular}{|c|c|c|c|c|c|}
\hline Bil & Istilah Kiri & Kolokasi & Istilah Kanan & Kekerapan & Peratus (\%) \\
\hline 1 & & mengasingkan & $\begin{array}{l}\text { dua perkara } \\
\text { iaitu }\end{array}$ & 1 & 1.02 \\
\hline 3 & mengecam, & mengasingkan & & 1 & 1.02 \\
\hline 5 & & mengasingkan & bahan asing & 2 & 2.04 \\
\hline 6 & & mengasingkan & diri & 28 & 28.6 \\
\hline 7 & & mengasingkan & $\begin{array}{c}\text { pelajar } \\
\text { berdasarkan } \\
\text { kaum }\end{array}$ & 4 & 4.08 \\
\hline 8 & & mengasingkan & $\begin{array}{l}\text { keuntungan } \\
\text { hasil } \\
\text { pelaburan }\end{array}$ & 1 & 1.02 \\
\hline 9 & & mengasingkan & ...dengan... & 7 & 7.14 \\
\hline 11 & & mengasingkan & sampah-sarap & 2 & 2.04 \\
\hline 15 & $\begin{array}{l}\text { menjemur } \\
\text { dan }\end{array}$ & mengasingkan & & 5 & 5.10 \\
\hline
\end{tabular}




\begin{tabular}{|c|c|c|c|c|c|}
\hline Bil & Istilah Kiri & Kolokasi & Istilah Kanan & Kekerapan & Peratus (\%) \\
\hline 16 & & mengasingkan & $\ldots$.dan... & 6 & 6.12 \\
\hline 20 & & mengasingkan & $\begin{array}{c}\text { pelajar } \\
\text { berdasarkan } \\
\ldots\end{array}$ & 4 & 4.08 \\
\hline 28 & & mengasingkan & $\begin{array}{c}\text { manusia } \\
\text { daripada } \\
\text { haiwan }\end{array}$ & 1 & 1.02 \\
\hline 29 & & mengasingkan & $\begin{array}{c}\text { yang benar } \\
\text { daripada yang } \\
\text { palsu }\end{array}$ & 1 & 1.02 \\
\hline 32 & & mengasingkan & ...mengikut.. & 2 & 2.04 \\
\hline 59 & & mengasingkan & $\begin{array}{c}\text { sesuatu } \\
\text { barangan }\end{array}$ & 1 & 1.02 \\
\hline 71 & $\begin{array}{l}\text { saya tidak } \\
\text { suka }\end{array}$ & mengasingkan & ...daripada... & 13 & 13.3 \\
\hline 72 & & mengasingkan & $\begin{array}{l}\text { kereta dengan } \\
\text { motosikal }\end{array}$ & 1 & 1.02 \\
\hline 76 & untuk & mengasingkan & & 14 & 14.3 \\
\hline 81 & proses & mengasingkan & & 2 & 2.04 \\
\hline 100 & $\begin{array}{l}\text { mengumpul } \\
\text { dan }\end{array}$ & mengasingkan & & 2 & 2.04 \\
\hline
\end{tabular}

\section{Huraian Korpus}

\section{Padan}

Berdasarkan carian korpus, perkataan 'padan' lebih banyak digunakan bersama perkataan 'dengan' yang membawa maksud sesuatu yang sesuai dan dilihat sepadan. Jika diamati dalam korpus ini dapat dilihat bahawa padan dengan merujuk kepada contoh korpus;

96989\#0 ...mengikut reka bentuk dan cara ia disusun, sesuai dan padan dengan gelaran nama yang diberi.

Hal ini demikian kerana penggunaan perkataan tersebut hampir tepat untuk menjelaskan keadaan yang dilihat sesuai dan sepadan. Perkataan 'padan' dianalisis sebagai perkataan yang menggambarkan sifat suatu benda yang berpasangan seperti sudu dengan garfu, baju dengan seluar, dan lelaki dengan perempuan. Berdasarkan temu 
bual bersama guru, konsep padanan didedahkan merujuk perkara yang mempunyai padanan pasangan yang tepat apabila murid faham maksud padan dengan baik, mereka mampu untuk mengenal pasti bentuk padanan yang sesuai misalnya, bentuk bulan padan dengan bintang.

\section{Padanan}

Penelitian korpus juga diamati pada leksikal padanan untuk meneliti kepelbagaian konteks bagi menjelaskan kemahiran prosedur dan terminologi awal Matematik bagi konsep tersebut kerana konteks pada kata padan amat terhad diperoleh dalam korpus. Menurut Kamus Dewan Edisi Keempat (2007), padanan bermaksud sesuatu yang padan, merupakan bandingan yang seimbang. Padanan ialah kata terbitan daripada perkataan padan. Ia bersinonim dengan perkataan padan dan beberapa perkataan lain seperti sesuai, cocok, layak, wajar, kena, dan banyak lagi berdasarkan korpus, perkataan padanan banyak menghuraikan ayat yang bersifat sepadan seperti padanan yang tepat, padanan yang sesuai, mencari padanan warna, padanan pakaian dan banyak lagi. Jadi, padanan sesuai harus merujuk kepada sebuah padanan yang mampu memadankan objek A dengan objek B dengan tepat dan tidak sekadar memadankan secara sebarangan. Berdasarkan korpus berikut dapat dilihat contoh korpus;

97509\#0. ...bilik tidur, pelamin dan langsir perlu disesuaikan dengan padanan warna.

Perkataan padanan dalam ayat seringkali digabungkan bersama 'dan', 'dengan', 'yang sama' kerana ia menggambarkan keadaan yang sepadan dan sesuai diletakkan bersama. Berdasarkan temu bual bersama guru konsep padanan juga didedahkan dalam PdPc, iaitu mempunyai maksud yang sama seperti padan, iaitu menunjukkan suatu keadaan yang sesuai misalnya, padanan yang tepat bagi kerusi ialah meja.

\section{Kumpul}

Menurut Kamus Dewan Edisi Keempat (2007), kumpul bermaksud himpun, berkelompok dan berkumpul di sesuatu tempat beramairamai atau dengan banyaknya. Kumpul juga sinonim dengan perkataan memungut atau mengutip sesuatu yang berselerak supaya 
menjadi sekelompok. Berdasarkan korpus, perkataan kumpul sering digunakan dalam ayat yang melibatkan pengumpulan wang, menyimpan wang serta mengumpulkan sebanyak mungkin harta benda. Terdapat juga makna ayat yang berkaitan dengan mengumpul tenaga, kuasa dan kekayaan serta kumpul maklumat yang diperlukan. Jelas di sini bahawa perkataan kumpul merupakan suatu keadaan menghimpunkan sesuatu daripada sedikit menjadi banyak. Jika diamati contoh korpus berikut;

103782\#0. ... sebulan dia perlukan 666 bulan untuk kumpul duit RM 100,000 .

Berdasarkan temu bual bersama guru, konsep kumpul boleh dihuraikan sebagai perbuatan menghimpun, meletakkan sesuatu secara berkumpulan atau mengikut kelompok tertentu. Perkara ini jelas menunjukkan kumpul ini bersinonim dengan operasi tambah (nilai bertambah). Misalnya, perbuatan mengumpul surat khabar lama untuk dihantar ke pusat kitar semula atau hobi seseorang yang gemar mengumpul setem lama.

\section{Banding}

Oleh sebab dapatan korpus sukar melihat gelagat kolokasi bagi leksikal membanding, maka dalam kajian ini penyelidik telah meneliti leksikal banding bagi melihat kolokasi dan gelagat konteksnya. Menurut Kamus Dewan Edisi Keempat (2007), perkataan banding bermaksud sama dengan, imbang tara. Sebagai contohnya, "Kehandalan Hang Tuah tidak ada bandingnya pada zaman itu." Maksud kedua banding ialah melihat dua benda untuk mengetahui apa-apa yang sama dan apa-apa yang berlainan. Berdasarkan korpus, perkataan banding banyak digunakan dalam konteks ayat yang menunjukkan perbezaan. Contoh korpus seperti berikut;

118462\#2. ...dipecahkan dalam penjuru dan bulatan bagi membezakan kadar banding antara setiap anggota tubuh.

Namun begitu, kebanyakan hasil carian melalui korpus menunjukkan banding sebagai nama tempat, iaitu Pulau Banding dan Tasik Banding. Terdapat juga beberapa ayat yang menjelaskan 
perbandingan sesuatu dengan sesuatu yang lain seperti kecantikan yang tiada bandingnya, kekayaan yang tidak terbanding, dan perbandingan terus seperti contoh korpus berikut;

100896\#0... Kita tidak boleh banding dengan Barat.”.

Berdasarkan temu bual bersama guru, konep banding lebih merujuk kepada perbandingan antara dua benda yang boleh diukur oleh pelajar seperti contoh, perbandingan saiz bola, perbandingan waktu, perbandingan jumlah duit dan banyak lagi. Hal ini demikian kerana terdapat perbezaan yang ketara antara dua objek menyebabkan pelajar akan lebih mudah untuk melakukan perbandingan.

\section{Asing/Mengasingkan}

Perkataan mengasingkan banyak menjelaskan keadaan seseorang yang menjauhkan diri daripada masyarakat. Sebagai contohnya, diamati korpus berikut;

114602\#0 Contohnya jika kita mengasingkan diri daripada masyarakat luar...

Terdapat juga ayat yang menggunakan perkataan mengasingkan bagi menunjukkan pemisahan dua benda seperti mengasingkan tempat tidur, mengasingkan biji benih, mengasingkan hasil pelaburan dengan modal, dan banyak lagi. Hal ini demikian kerana perkataan mengasingkan jelas memberi kefahaman bahawa berlakunya pengasingan antara dua perkara atau lebih. Begitu juga apabila sesuatu perbuatan yang melibatkan seseorang perlu mengasingkan barang atau dalam erti kata lain memisahkan barang tersebut daripada barangan lain. Berdasarkan temu bual bersama guru, konsep asing diterjemah menerusi guru membuat permintaan supaya pelajar mengasingkan buku latihan dengan buku teks di atas meja. Selain itu, arahan seperti meminta pelajar mengasingkan beberapa biji bola yang berbeza warna untuk diletakkan di dalam bekas mengikut warna yang sama. Pelajar akan mengelakkan daripada berlakunya percampuran warna dan memisahkan bola-bola tersebut mengikut arahan guru. 


\section{KESIMPULAN}

Berdasarkan pengamatan terhadap kolokasi bagi kata padan, padanan, kumpul, asing dan mengasingkan, maka penyelidik dapat mengamati bahawa pengajaran awal Matematik bagi konsep-konsep tersebut harus telus dan tepat. Hal ini bertujuan agar kanak-kanak dapat memahami dengan baik kemahiran prosedur dan terminologi bagi konsep-konsep tersebut. Dengan kata lain, pengajaran awal Matematik perlu bercirikan pembinaan konsep dan pemaknaan yang komprehensif sifatnya.

Penggunaan bahasa dalam pembelajaran dan pemudahcaraan awal Matematik akan menjadi lebih jelas jika disertai dengan teori atau model bahasa yang efisien bagi menangani kekaburan dalam memahami konsep mengikut kemahiran prosedur dan terminologi awal Matematik secara relasional. Kekangan dari sudut bahasa berperkataan yang digunakan oleh para guru prasekolah dalam pengajaran dan pembelajaran awal Matematik diterjemahkan melalui kegagalan guru menggunakan istilah yang tepat dalam menggambarkan kemahiran prosedur dan terminologi dalam bidang ini. Konflik ini telah menyebabkan pemahaman terhadap sesuatu konsep Matematik meliputi kemahiran prosedur dan terminologinya yang diajar perlu menjadi lebih kompleks kerana murid sukar menggarap makna daripada istilah dan konstruk dalam operasi Matematik, iaitu melibatkan strategi pengajaran bermakna menerusi kepelbagaian konteks aktiviti yang dijelmakan menerusi pengajaran berasaskan leksis.

\section{PENGHARGAAN}

Artikel ini merupakan hasil penyelidikan Geran Penyelidikan Universiti GPU 2017-0228-107-01 yang bertajuk Pembangunan Kit Leksikal Bagi Menangani Kekaburan Kemahiran Prosedur Dan Terminologi Matematik Dalam Kalangan Kanak-Kanak Permata Negara. Penghargaan kepada RMIC, UPSI atas tawaran geran ini .

\section{RUJUKAN}

Aiken, L. R. Jr. (1973). Ability and creativity in mathematics. Columbus, Ohio: ERIC Information Center. 
Ashaari, Z. M., Mohd Kosnin, A., \& Jiar, Y. K. (2013). Keberkesanan modul belajar melalui bermain terhadap kefahaman pengalaman pranombor kanak-kanak prasekolah. Prosiding 2nd International Seminar on Quality and Affordable Education (ISQAE) 2013. Kuala Lumpur.

Aunio, P., \& Niemivirta, M. (2010). Predicting children's mathematical performance in grade one by early numeracy. Learning and Individual Differences, 20(5), 427-435.

Bley-Vroman. (1989). What is the logical of foreign language learning? In Susan M. Guss, Jacquelyn Schachter. Linguistic Perspective on Second Language Acquisition. New York: Cambridge University Press.

Bradby, D., Owings, J., \& Quinn, P. (1992). Language characteristics and academic achievement: A look at Asian and Hispanic eighth graders in NELS: 88. Statistical Analysis Report. Berkeley: MPR Associates. (ED 343 971).

Bryant, P., \& Nunes, T. (2002). Children's understanding of mathematics. In U. Goswami (Ed.), Blackwell handbook of childhood cognitive development (pp. 412-439). Malden, The Netherlands: Blackwell.

Clement, R .(1980). Ethnicity, contact and communicative competence in a second language. In. Giles, H. M., Robinson, W. P., \& Smith, P. M., Eds., Language: Social Psychological Perspectives, 147-154.

Clements, D. (1999). Teaching length measurement: Research challenges. School Science and Mathematics, 99(1), 5-11.

Clements, D. H., \& Sarama, J. (2007). Effects of a preschool Mathematics curriculum: Summative research on the Building Blocks project. Journal for Research in Mathematics Education, 38 (2), 136-163.

Clements, D. H., \& Sarama, J. (2014). The Importance of the Early Years. In R. E. Slavin (Ed.), Science, Technology \& Mathematics (STEM). Thousand Oaks, CA: Corwin.

Cross, C. T., Woods, T. A., \& Schweingruber, H. (Eds.). (2009). Mathematics Learning in Early Childhood: Paths Toward Excellence and Equity. Washington, DC, US: National Academies Press.

Dowker, A. (2005). Individual Differences in Arithmetic: Implications for Psychology, Neuroscience and Education. Hove, UK: Psychology Press. 
Firth, J. R. (1957). A Synopsis of Linguistic Theory, 1930-1955. In Liu Runqing et al (Eds). Readings in Linguistics: SeventyFive Years Since Saussure. Vol. 1, 328-359. Beijing: Cehui Press.

Ginsburg, H. P., Cannon, J., Eisenband, J. G., \& Pappas, S. (2006). Mathematical thinking and learning. In K. McCartney \& D. Phillips (Eds.), Handbook of early child development (pp. 208-229). Oxford, UK: Blackwell.

Hashim, N. H., \& Che Lah, Y. (2003). Panduan pendidikan prasekolah. Pahang: PTS Publications \& Distributors Sdn. Bhd.

Husin, Z. (2014). Komunikasi dalam penyelesaian masalah matematik dalam kalangan murid tingkatan empat. (Tesis Doktor Falsafah). Universiti Sains Malaysia.

Jalaluddin, N. H., Sarudin, A., \& Ahmad, Z. (2012). Peluasan makna alim: Analisis semantik kognitif. GEMA Online ${ }^{\mathrm{TM}}$ Journal of Language Studies, 12(2), 457-473.

Jamison, R. E. (2000). Learning the language of Mathematics. Retrieved from https://wac.colostate.edu/llad/v4n1/jamison. pdf.

Konting, M. M. (2005). Kaedah penyelidikan pendidikan. Kuala Lumpur: Dewan Bahasa dan Pustaka. Korpus DBP. Diperoleh dari: http://sbmb.dbp.gov.my/korpusdbp/SelectUserCat.aspx

Kuhn, D. (2000). Metacognitive development. Current Directions in Psychological Science, 9(5), 178-181.

Loretta C. Rudd., Macy Satterwhite., \& Matthew C. Lambert. (2010). One, two, buckle my shoe: Using math-mediated language in preschool. Dimensions of Early Childhood, 38(2), 30-38.

Louw, W. E. (1993). Irony in the text or insincerity in the writer? The diagnostic potential of semantic prosodies. Text and Technology: In Honour of John Sinclair. (pp. 157-176). Amsterdam: John Benjamins.

Marican, S. (2016). Penyelidikan sains sosial: Pendekatan pragmatik. Batu Caves: Edusystem.

Mohd Faizal Nizam., Lee, A., \& Tze, W. L. (2017). Kesahan dan kebolehpercayaan instrumen penilaian kendiri pembelajaran geometri Tingkatan Satu. Malaysian Journal of Learning and Instruction, 14(1), 211-265.

Mohd Kosnin, A., \& Mohd Khalid, S. H. (2010). Strategi-strategi dalam penyelesaian masalah Matematik berperkataan dalam kursus statistik 1. Skudai: Universiti Teknologi Malaysia. 
NAEYC. (2001). NAEYC Standards for Early Childhood Professional Preparation.Washington, DC: Author.

National Association for the Education of Young Children (NAEYC) and National Council of Teachers of Mathematics (NCTM). (2002, April; updated 2010). Early childhood Effects of Big Math for Little Kids 43 mathematics: Promoting good beginnings. (Position statement). Retrieved from NAEYC website: www.naeyc.org/files/naeyc/file/positions/psmath. pdf.

National Council of Teachers of Mathematics (NCTM). (2000). Principles and Standards for School Mathematics. Reston, Va: Publisher.

Pappas, S., Ginsburg, H., \& Jiang, M. (2003). SES differences in young children's metacognition in the context of Mathematical problem solving. Cognitive Development, 18, 43-450.

Puteri Roslina, A. W. (2005). Definisi dan konteks dalam terminologi Bahasa Melayu. Jurnal Pengajian Melayu, 16, 55-71.

Rudd, L. C., Lambert, M. C., Satterwhite, M., \& Zaier, A. (2008). Mathematical language in early childhood settings: What really counts? Early Childhood Education Journal, 36(1), 75-80.

Samian, A. L. (1997). Falsafah Matematik. Selangor: Percetakan Dewan Bahasa \& Pustaka.

Sarudin, A., \& Jalaluddin, N. H. (2015). Peluasan makna wakaf: Analisis berdasarkan proses dan prinsip kognitif. Pertanika Mahawangsa, 2(2), 9-30 .

Sarudin, A., Raja Ma'amor Syah, R. N. F. A., Mohamed Redzwan, H. F., Osman, Z., Othman, W. M., Mohd Ariff Albakri, I. S. (2019). Lexical approach: Overcoming vague skills procedure and early Mathematical terminology based on the prosodic semantic theory. Journal of Mechanics of Continua and Mathematical Sciences, 14(3), 94-111.

Sekaran, U., \& Bougie, R. (2016). Research methods for business: A skill-building approach (7th Ed.). Haddington: John Wiley \& Sons.

Seo, K.-H., \& Ginsburg, H. P. (2004). What is developmentally appropriate in early childhood Mathematics education? Lessons from new research. In D. H. Clements, J. Sarama, \& A.-M. DiBiase (Eds.), Engaging Young Children in Mathematics: Standards for Early Childhood Mathematics 
Education (pp. 91-104). Hillsdale, NJ: Lawrence Erlbaum Associates.

Sie Na, Chong., Chong Siew Ha., \& Rosli, R. (2017). Penggunaan kaedah cubes dalam penyelesaian masalah Matematik berayat Tahun 6. Simposium Pendidikan Diperibadikan: Perspektif Risalah An-Nur (SPRiN2017), 42-56.

Sinclair, J. (1996). The search for units of meaning. Textus IX, 75106.

Stanic, G. M. A., \& Kilpatrick, J. (1992). Mathematics curriculum reform in the United States. A historical perspective. International Journal of Educational Research, 17, 407-437.

Starkey, P., \& Klein, A. (2008). Sociocultural influences on young children's Mathematical knowledge. In Contemporary Perspectives on Mathematics in Early Childhood Education (pp. 253-276). Charlotte, NC: Information Age Publishing.

Stern, E. (1993). What makes certain arithmetic word problems involving the comparison of sets so hard for children? Journal of Educational Psychology, 85, 7-23.

Tengku Zainal, T. Z., Mustapha, R., \& Abdul Razak. (2009). Pengetahuan pedagogi isi kandungan guru Matematik bagi tajuk pecahan: Kajian kes di sekolah rendah. Jurnal Pendidikan Malaysia, 34(1), 131-153.

Wilder, R. L. (2010). Matematik suatu budaya. Shaharir Mohamed Zain (Terj.). Bangi: Penerbit Universiti Kebangsaan Malaysia. Yahaya, A., Hashim, S. Ramli., S., Boon Y., \& Hamdan, A. R. (2007). Menguasai penyelidikan dalam pendidikan. Edisi Kedua. Kuala Lumpur: PTS Professional Publishing Sdn Bhd. Yahaya, A., \& Elanggovan. (2010). Kepentingan kefahaman konsep dalam Matematik. Universiti Teknologi Malaysia. Diperoleh daripada http://eprints.utm.my/id/eprint/10413/ 